\title{
O RECURSO ORDINARIO NO MANDADO DE SEGURANÇA
}

\author{
Ernani Guarita Cartaxo \\ Professor Catedrático da Faculdade de Direito \\ da Universidade do Paraná
}

Estabelece a Constituição Federal, em matéria de mandado de segurança, o recurso ordinário, para o Supremo Tribunal, da decisão de última instância, proferida pelos Tribunais locais ou federais, quando denegar o mandado (art. 101, II, a), e o extraordinário, nos casos previstos no art. 101, n. III, a e d.

O recurso ordinário obriga o Supremo Tribunal a conhecer de matéria diversa da questão federal, compelindo-o a decidir sôbre a aplicação de leis estaduais e até municipais, segundo o seu próprio mérito ou a sua exegese autônoma.

Cria-se assim uma terceira instância, com duas conseqüências inafastáveis: de uma parte, o visível desvirtuamento das funções do Supremo, a que se devolve o julgamento de questões de direito local, do que decorre indisfarçável ofensa ao sistema federativo; e, de outra parte, a preeminência processual do mandado, em cotejo com as demais ações, que sòmente são recorríveis para o Supremo, extraordinàriamente, e mesmo quando comportarem questão federal.

O mandado de segurança obtém dess a forma absoluta superioridade sôbre o sistema processual ordinário. Daí a abusiva preferência que lhe é dada, pela virtude excepcional do seu alcance, dado que o princípio constitucional concessivo do recurso ordinário pressupõe no sentido denegatório da medida uma possível injustiçe dos tribunais locais, favorável à manutenção dos atos de suas autoridades, abusivos ou ilegais, em ordem de exigir a apreciação tutelar do Supremo Tribunal.

Dêsse modo, certas questões principalmente de natureza fiscal, estadual ou municipal, e bem assim aque-

Indicação apresentada ao Congresso Nacional de Direito, reunido em Fortaleza Ceará, em 6 de Outubro de 1959. 
las pertinentes à organização e interêsses do funcionalismo público, estadual e municipal, são o objetivo predileto do mandado de segurança, dado que o especificismo do seu mérito, integrado no mecanismo peculiaríssimo do meio local, pode admitir, na esfera federal, soluções divergentes daquelas que o tradicionalismo doutrinário e jurisprudencial do meio de origem tem assentado como a communis opinio, formada ao calor do princípio constitucional da autonomia dos Estados, no que toca aos seus interêsses particulares, sujeitos à tutela das justiças locais.

O regime federativo impõe o resguardo das normas de competência dos órgãos do Poder Judiciário, de forma a assegurar às justiças locais - conhecimento exclusivo das questões, que envolvam interêsses regulados pela legislação local, e não interfiram direta ou indiretamente com a Constituição Federal ou lei federal.

Tais princípios são desautorizados pela admissibilidade do recurso grdinário das decisões da justiça local, denegatórias do mandado de segurança, ainda que proferidas na ausência de qualquer questão federal.

Que dizer-se então da competência dada ao Supremo para apreciar o mérito dos simples atos da autoridade local, cuja ilegalidade ou abusividade tenha sido contestada pela decisão denegatória do mandamus?

Não se argumente com a equiparação que se faz na Constituição Federal entre o habeas-corpus e o mandado de segurança (art. 101, II, a), para se concluir pela razoabilidade do recurso ordinário, que se outorga às decisôes denegatórias de ambas ăs medidas. É que, no sistema da Constituição, o habeas-corpus nada mais é que o remedium juris destinado a garantir a liberdade do homem, e é sabido que os direitos, que concernem a essa liberdade, sob qualquer aspecto, estão sob a imediata proteção da Constituição (art. 141), o que não sucede com os direitos líquidos e certos, a que se refere o texto constitucional, que entende protegê-los pela segurança.

Nessa equiparação, aliás, é que reside o equívoco da Constituição, pois só por equívoco é que se pode dizer que o mandado de segurança se destina a proteger direito líquido e certo não amparado por habeas-corpus, dado que 0 habeas-corpus não foi criado para amparar nenhum direito líquido e certo. A liberdade não é direito dêsse gênero, pois enquanto os direitos líquidos e certos são direitos derivados, decorrentes da lei ou constituídos sob a sua proteção, a liberdade é um direito fundamental, que a lei reconhece, mas não cria.

O mandado de segurança é uma ação, de rito sumaríssimo e de natureza civil.

Dar-lhe recurso ordinário para o Supremo Tribunal, no caso de decisão denegatória por parte dos tribunais locais, é subverter a sistemática processual dominante, é desnaturar o regime normal de competência da mais alta Côrte Federal e incentivar até ao abuso a prática do mandado de segurança, pelo propósito de desaforar do âmbito das justiças locais, em favor de uma terceira instância, questões de competência normal dos tribunais estaduais. 